\title{
SEISMIC EVALUATION OF RC FRAMED BUILDINGS WITH INFLUENCE OF MASONRY INFILL PANEL
}

\author{
Md Irfanullah ${ }^{1}$, Md Irshad Ali ${ }^{2}$, Vishwanath. B .Patil ${ }^{3}$ \\ ${ }^{1,2}$ P.G. Student, ${ }^{3}$ Professor, Structural Engineering Department, P.D.A.College of Engineering, Gulbarga-585102, \\ Karnataka, India \\ mdirfanullah36@gmail.com,mdirshadali1988@gmail.com,vickyglb@gmail.com
}

\begin{abstract}
$R C$ framed buildings are generally designed without considering the structural action of masonry infill walls present. These walls are widely used as partitions and considered as non-structural elements. But they affect both the structural and non-structural performance of the RC buildings during earthquakes. RC framed building with open first storey is known as soft storey, which performs poorly during earthquakes. A similar soft storey effect can also appear below plinth, when the ground material has removed during excavation and refilled later. To observe the effect of masonry infill panel, it is modeled as an equivalent diagonal strut. In order to study these six RC framed buildings with brick masonry infill were designed for the same seismic hazard. In the present paper an investigation has been made to study the behavior of $R C$ frames with various arrangement of infill when subjected to earthquake loading. The results of bare frame, frame with infill, soft ground floor, soft basement and infill in swastika pattern in ground floor are compared and conclusions are made. It is observed that, providing infill below plinth and in swastika pattern in the ground floor improves earthquake resistant behavior of the structure when compared to soft basement.
\end{abstract}

Key words: masonry infill panel, bare frame, soft basement, diagonal strut.

\section{INTRODUCTION}

In many countries RC frames are infilled fully or partially by masonry infill panels with or without openings. Since these panels significantly enhance both the stiffness and strength of the frame, their contribution is not taken into account because of the lack of knowledge of the composite behavior of the infilled frame. In the present practice of structural design in India, masonry infill panels are treated as non- structural element and their strength and stiffness contribution are neglected. In fact the presence of infill wall changes the behavior of the frame action in to truss action, thus changing the lateral load transfer mechanism. Performance of buildings in the past earthquakes clearly illustrates that the presence of infill walls has significant structural implications. Therefore, we cannot simply neglect the structural contribution of infill walls particularly in seismic regions where, the frame-infill interaction may cause significant increase in both stiffness and strength of the frame in spite of the presence of openings. Objective of present study is to find effect of infill's in the frame and also the behavior of structure below plinth. The structure below plinth is normally assumed to perform like a soft storey with loose soil material filled after excavation. To lay down the column foundation for the structure the material adjoining the column and footing is excavated and re filled after completion of foundation work. The frame thus formed above the footing level and up to the ground level is infilled with loosely filled material and fails to give similar effect of infill masonry and acts like a soft basement. The analysis and design provisions related to masonry infilled RC frames in seismic design codes of different countries shows that only a few codes have considered the effect of infill in analysis and design of masonry infilled RC frames. In the case of horizontal loading due to wind or seismic action, it is usual to assume that an equivalent compression strut can replace the action of the masonry infill panels.

\section{DESCRIPTION OF STRUCTURAL MODEL}

For the study six different models of an eleven storey building are considered the building has five bays in $\mathrm{X}$ direction and five bays in $\mathrm{Y}$ direction with the plan dimension $25 \mathrm{~m} \times 20 \mathrm{~m}$ and a storey height of $3.5 \mathrm{~m}$ each in all the floors and depth of foundation taken as $1.5 \mathrm{~m}$. The building is kept symmetric in both orthogonal directions in plan to avoid torsional response. The orientation and size of column is kept same throughout the height of the structure. The building is considered to be located in seismic zone V. The building is founded on medium strength soil through isolated footing under the columns. Elastic moduli of concrete and masonry are taken as 27386 $\mathrm{MPa}$ and $5500 \mathrm{MPa}$ respectively and their poisons ratio as 0.20 and 0.15 respectively.

Different types of analytical models with the understanding of behavior of infill panels were developed. Out of all methods, method based on equivalent structural approach (Stafford 
Smith1966) is simple and easier to apply in practical design. The single strut model is the most widely used as it is simple suitable for large structures. Response reduction factor for the special moment resisting frame has taken as 5.0 (assuming ductile detailing). The unit weights of concrete and masonry are taken as $25.0 \mathrm{KN} / \mathrm{m} 3$ and $20.0 \mathrm{KN} / \mathrm{m} 3$ respectively the floor finish on the floors is $1.5 \mathrm{KN} / \mathrm{m} 2$. The live load on floor is taken as $3.5 \mathrm{KN} / \mathrm{m} 2$. In seismic weight calculations, $50 \%$ of the floor live loads are considered.

\section{MODEL CONSIDERED FOR ANALYSIS}

Following six models are analyzed as special moment resisting frame using equivalent static analysis and response spectrum analysis.

Model I: Bare frame model, however masses of infill walls are included in the model.

Model II: Full infill masonry model. Building has one full brick infill masonry wall in all storeys including the first storey and below plinth.

Model III: Building has one full brick infill masonry wall in all storeys except below plinth.

Model IV: Building has no wall in the first storey and one full brick infill masonry wall in upper storeys and below first storey.

Model V: Building has no wall in first storey and basement and one full brick infill masonry wall in upper stories, above first storey.

Model VI: Building similar to model 5 but with infill walls in the swastika pattern in the ground storey. (Refer fig.1)

\section{MODELING OF FRAME MEMBERS AND MASONRY INFILL}

The frame members are modeled with rigid end conditions, the floors are modeled as diaphragms rigid in plane and walls are modeled as panel elements without any opening. The frames with unreinforced masonry walls can be modeled as equivalent braced frames with infill walls replaced by equivalent diagonal strut. Many investigators have proposed various approximations for the width of equivalent diagonal strut. The width of strut depends on the length of contact between the wall \& the columns $\left(\alpha_{h}\right)$ and between the wall $\&$ the beams $\left(\alpha_{\mathrm{L}}\right)$. The formulations for $\alpha_{\mathrm{h}}$ and $\alpha_{\mathrm{L}}$ on the basis of beam on an elastic foundation has been used given by Stafford Smith (1966). Hendry (1998) proposed the following equation to determine the equivalent or effective strut width $\mathrm{w}$, where the strut is assumed to be subjected to uniform compressive stress.

$$
\alpha_{h}=\frac{\pi}{2} \sqrt[4]{\frac{4 E_{f} I_{c} h}{E_{m} t \sin 2 \theta}}
$$

$$
\begin{gathered}
\alpha_{L}=\pi \sqrt[4]{\frac{4 E_{f} I_{b} L}{E_{m} t \sin 2 \theta}} \\
w=\frac{1}{2} \sqrt{\alpha_{h}^{2}+\alpha_{L}^{2}}
\end{gathered}
$$

Where

$\mathrm{E}_{\mathrm{m}}$ is elastic modulus of masonry wall, $\mathrm{E}_{\mathrm{f}}$ is elastic modulus of frame material, $\mathrm{t}$ is thickness of infill,

$h$ is height of infill and $L$ is length of infill,

$I_{c}$ is moment of inertia of the column, $I_{b}$ is moment of inertia of the beam and $\theta=\tan ^{-1}(\mathrm{~h} / \mathrm{L})$.

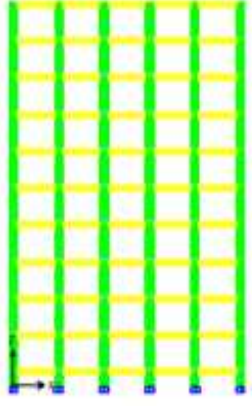

Model 1

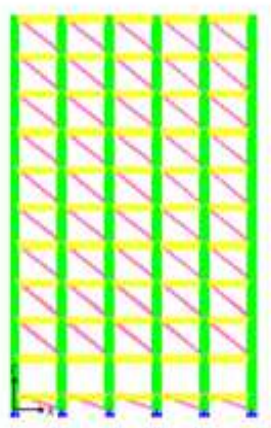

Model 4

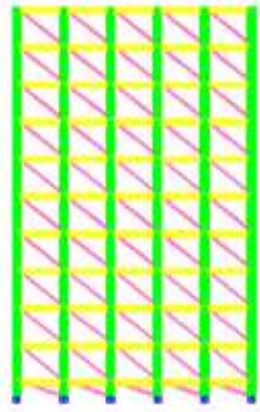

Model2

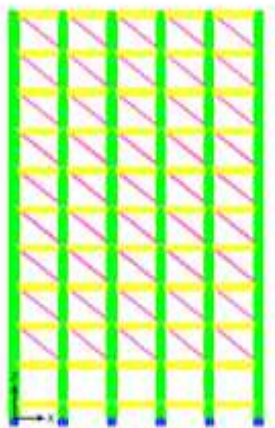

Model 5

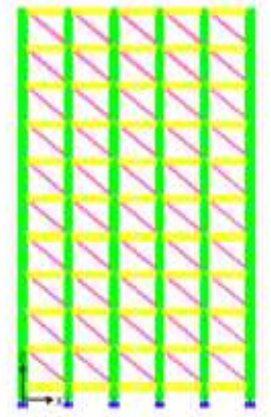

Model3

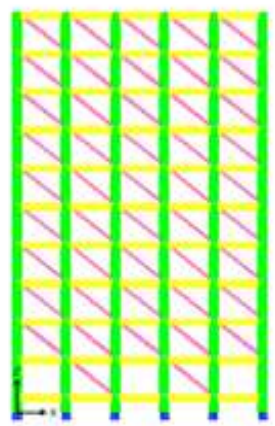

Model 6
Fig. 1: Elevation of eleven storey reinforced concrete building

\section{ANALYSIS OF THE BUILDING}

Equivalent static and response spectrum analyses has been performed as per IS 1893 (part-1) 2002 for each model using ETABS 9.6 (computer and structures) software. Lateral load calculation and its distribution along the height is done. The seismic weight is calculated using full dead load plus $50 \%$ of live load. The results obtained from analyses are compared with respect to the following parameters. 


\subsection{Fundamental Time Period:}

Table 1: Comparison of time period by IS code method and analysis using ETABS software.

\begin{tabular}{|c|c|c|c|c|}
\hline \multicolumn{5}{|c|}{ Fundamental time period (sec.) } \\
\hline \multirow[t]{2}{*}{ Model No. } & \multicolumn{2}{|c|}{ IS Code 1893-2002 } & \multicolumn{2}{|c|}{ ETABS Analysis (RSA) } \\
\hline & longitudinal & transverse & longitudinal & transverse \\
\hline 1 & 1.113 & 1.113 & 2.133 & 2.133 \\
\hline 2 & 0.657 & 0.734 & 0.538 & 0.538 \\
\hline 3 & 0.657 & 0.734 & 0.555 & 0.555 \\
\hline 4 & 0.657 & 0.734 & 0.731 & 0.731 \\
\hline 5 & 0.657 & 0.734 & 0.816 & 0.816 \\
\hline 6 & 0.657 & 0.734 & 0.579 & 0.579 \\
\hline
\end{tabular}

\subsection{Seismic Base Shear:}

Table.2: Comparison of seismic base shear

\begin{tabular}{|c|c|c|c|c|c|c|}
\hline \multicolumn{7}{|c|}{ Base shear $(\mathrm{kN})$} \\
\hline \multicolumn{3}{|c|}{ IS Code 1893-2002 } & \multicolumn{2}{|c|}{ ESA (ETABS) } & \multicolumn{2}{|c|}{ RSA (ETABS) } \\
\hline Model No. & longitudinal & transverse & longitudinal & transverse & longitudinal & transverse \\
\hline 1 & 4590.24 & 4590.24 & 15548.7 & 15548.7 & 4181.89 & 4015.31 \\
\hline 2 & 12648.51 & 11395.06 & 23263.89 & 23263.89 & 22430.36 & 20665.14 \\
\hline 3 & 12545.12 & 11301.91 & 23059 & 23059 & 22961.24 & 20606.28 \\
\hline 4 & 12166 & 10960.36 & 22307.6 & 22307.6 & 20310.47 & 17270.35 \\
\hline 5 & 12062.6 & 10867.21 & 22102.7 & 22102.7 & 18670.2 & 16223.69 \\
\hline 6 & 12320 & 11099.05 & 22612.7 & 22612.7 & 21647 & 20030.72 \\
\hline
\end{tabular}

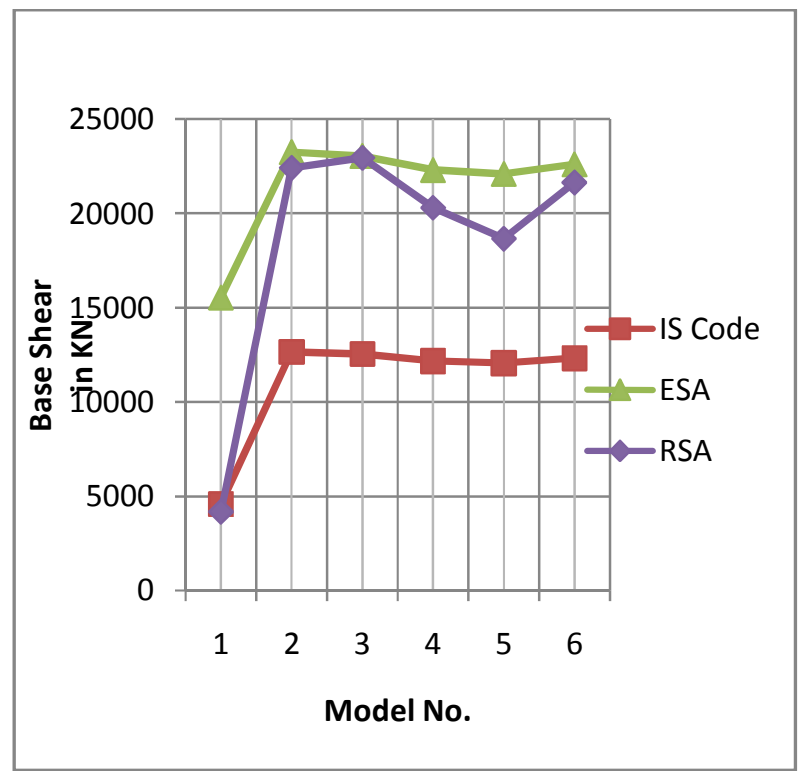

Fig.2: Base shear Vs Model No. for various models along longitudinal direction. 


\subsection{Storey Drift:}

Table.3: Storey Drift for various models along longitudinal direction.

\begin{tabular}{|l|l|l|l|l|l|l|}
\hline \multicolumn{7}{|l}{ Storey Drift(mm) } \\
\hline & Model 1 & Model 2 & Model 3 & Model 4 & Model 5 & Model 6 \\
\hline Storey & ux & ux & ux & ux & ux & ux \\
\hline 11 & 3.414 & 0.354 & 0.349 & 0.346 & 0.34 & 0.344 \\
\hline 10 & 4.75 & 0.639 & 0.427 & 0.422 & 0.416 & 0.421 \\
\hline 9 & 6.221 & 0.669 & 0.494 & 0.489 & 0.482 & 0.488 \\
\hline 8 & 7.532 & 0.667 & 0.551 & 0.545 & 0.537 & 0.544 \\
\hline 7 & 8.562 & 0.657 & 0.595 & 0.589 & 0.581 & 0.588 \\
\hline 6 & 9.254 & 0.636 & 0.628 & 0.622 & 0.613 & 0.621 \\
\hline 5 & 9.546 & 0.603 & 0.649 & 0.644 & 0.636 & 0.644 \\
\hline 4 & 9.302 & 0.559 & 0.66 & 0.646 & 0.637 & 0.654 \\
\hline 3 & 8.183 & 0.502 & 0.66 & 0.749 & 0.755 & 0.667 \\
\hline 2 & 5.412 & 0.433 & 0.657 & 2.081 & 2.554 & 0.808 \\
\hline 1 & 1.622 & 0.355 & 0.609 & 0.523 & 1.233 & 0.659 \\
\hline
\end{tabular}

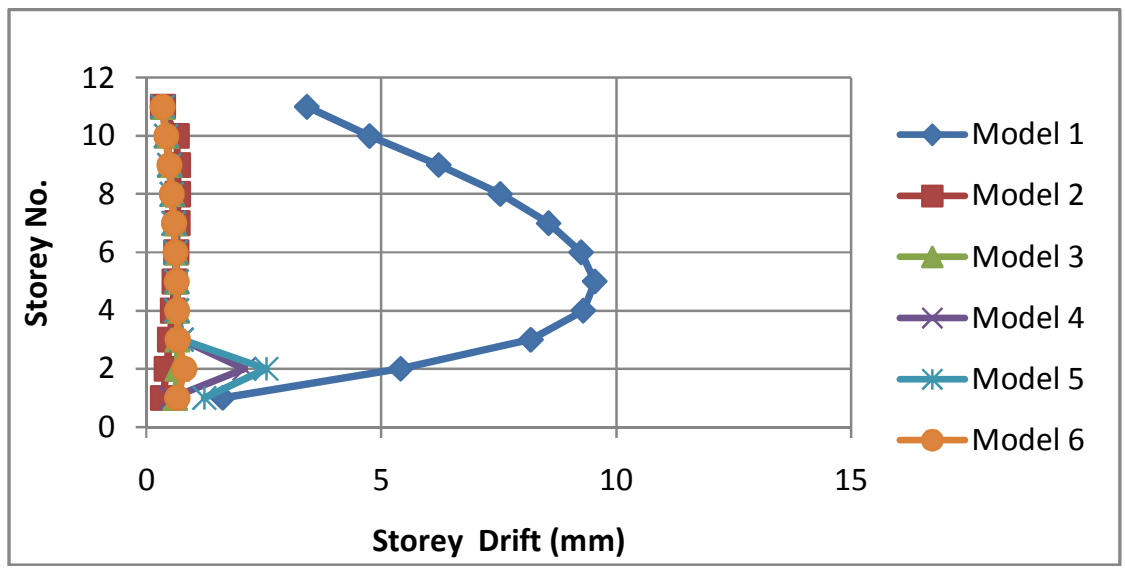

Fig.3: Storey Vs Storey drift for various models along longitudinal direction.

\subsection{Storey Displacement:}

Table 4: Displacement for each model along longitudinal direction

\begin{tabular}{|l|l|l|l|l|l|l|}
\hline & \multicolumn{6}{|l}{ Displacement $(\mathrm{mm})$} \\
\hline & Model 1 & Model 2 & Model 3 & Model 4 & Model 5 & Model 6 \\
\hline Storey & ux & ux & ux & ux & ux & ux \\
\hline 11 & 255.1 & 10 & 10.3 & 16.3 & 19 & 11 \\
\hline 10 & 243.1 & 9 & 9.3 & 15.3 & 18 & 10 \\
\hline 9 & 226.5 & 7.9 & 8.2 & 14.2 & 16.9 & 8.9 \\
\hline 8 & 204.7 & 6.7 & 7 & 13 & 15.8 & 7.7 \\
\hline 7 & 178.3 & 5.4 & 5.8 & 11.8 & 14.6 & 6.5 \\
\hline
\end{tabular}




\begin{tabular}{|l|l|l|l|l|l|l|}
6 & 148.4 & 4.2 & 4.6 & 10.7 & 13.5 & 5.4 \\
\hline 5 & 116 & 3.1 & 3.5 & 9.6 & 12.4 & 4.3 \\
\hline 4 & 82.6 & 2.1 & 2.6 & 8.6 & 11.5 & 3.3 \\
\hline 3 & 50 & 1.3 & 1.7 & 7.9 & 10.7 & 2.5 \\
\hline 2 & 21.4 & 0.6 & 1.1 & 6.9 & 9.7 & 1.9 \\
\hline 1 & 2.4 & 0.2 & 0.6 & 0.5 & 1.8 & 0.8 \\
\hline
\end{tabular}

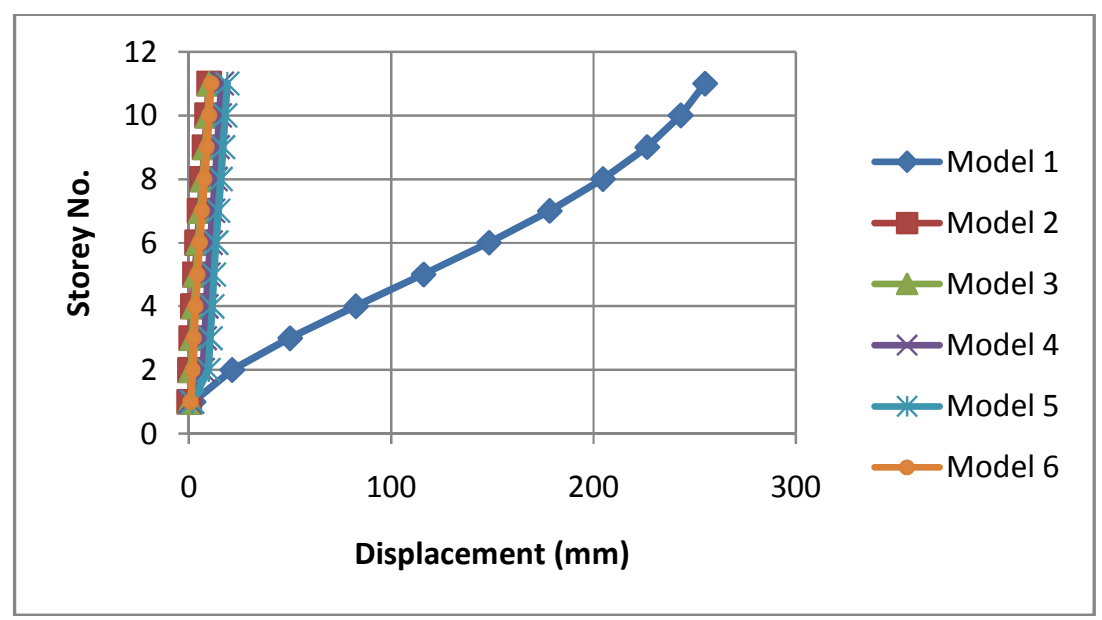

Fig.4: Storey Vs Displacement for various models along longitudinal direction.

\section{RESULTS AND DISCUSSIONS}

It is observed that model I gives higher time period compared to other models. Also time period is almost twice for model I from ETABS compared to IS code. Time period for model 4 is 0.731 and model 1 has 2.133.It shows that the use of infill below plinth reduces time period. Walls in swastika pattern in ground floor reduces time period by $29 \%$ as compared to model 5. Thus the provision of infill wall justifies the reduction in time period. It is also observed that lateral stiffness in different models under consideration are increasing with the addition of infill compared to situation when infill is not provided.

The seismic base shear values obtained from IS code and ESA (ETABS) for various models do not differ much compared to RSA values. The values obtained from code and ESA (ETABS) are not in a good agreement. Further RSA yields more effective base shear values compared to ESA.

The storey drift of Model IV is 67\% less compared to Model I at the first floor level. It is therefore concluded that the infill wall can be a good solution to reduce the storey drift at basement level. Also the drift of model VI is $68 \%$ less compared to Model V at second storey level. Hence it can be concluded that instead of keeping the ground storey as a soft one it is better to provide infill in particular directions such that parking facility do not get obstructed.
The lateral displacement is very large for bare frame model compared to other models. At storey 2 level, the storey displacement of Model IV is $67 \%$ lesser than Model I and at top storey level the displacement of Model IV is $93 \%$ lesser than Model I. Comparing model V and VI it is observed that at storey level 2, the displacement of model VI is $80 \%$ lesser and at top it is $42 \%$ lesser than model V. Thus it can be concluded that addition of infill act as drift and displacement controlled elements in RC buildings.

\section{CONCLUSIONS}

The fundamental time period of the building decreases when the effect of masonry infill wall is considered. This clearly indicates that the masonry infill panel has structural implications and should not be ignored in the analysis. The seismic base shear values obtained from IS code is not in a good agreement with the values obtained from ESA (ETABS). Further it has been found that the calculation of earthquake forces by treating the building as bare frame results in an underestimation of base shear. The storey drift for all models satisfy the permissible limit $0.004 * \mathrm{~h}$ where $\mathrm{h}$ is the storey height, as per IS 1893. The displacement demand is very high for bare frame model. Thus the provision of infill wall enhances the performance in terms of storey displacements. 


\section{ACKNOWLEDGMENTS}

The authors wish to thank the Management, Principal, Head of Civil Engineering Department, Organizing Secretary, and Staff of Poojya Doddappa Appa College of Engineering for their encouragement and support.

\section{REFERENCES}

[1]. Sachin. R. Patel and Sumant. B. Patel ,'Effect of Brick Infill Panel in Design of High Rise Building", National Conference on Recent Trends in Engineering \& Technology,(2011).

[2]. C.V.Murthy and Sudhir. K. Jain, "Benefecial Influence of Masonry Infill Walls on Seismic Performance of RC Frame Buildings", 12WCEE2000, paper 1790, pg.2-5.

[3]. Amit. V. Khandve, "Seismic response of RC frames buildings with soft first storeys", International Journal of Engineering Research and Applications (IJERA), ISSN 22489622, Vol.2, Issue 3,May-June 2012,pp 2100-2108.

[4]. Das, D. \& Murty, C. V. R. 2004. "Brick masonry infills in seismic design of RC framed buildings" Part 1 -Cost implications. The Indian Concrete Journal July 2004, vol78 No7: 39-43.

[5]. Pankaj Agarwal and Manish Shrikhande "Earthquake Resistant Design of Structures", New Delhi.

[6]. IS 1893 (Part I), (2002) "Criteria for Earthquake Resistant Design of Structures.” Bureau of Indian Standards, New Delhi 